\title{
The Predictor Effect of Insight and Cognitive Flexibility on Psychological Hardiness
}

\section{İçgörü ve Bilişsel Esnekliğin Psikolojik Dayanıklılık Üzerindeki Yordayıc Etkisinin İncelenmesi}

\author{
Muhammet Enes Kaya ${ }^{1}$, Furkan Onur Eken ${ }^{1}$, Durmuş Ümmet ${ }^{2}$
}

\begin{abstract}
:
In this research, it was aimed to examine the effect of insight and cognitive flexibility on psychological hardiness. In the study group, there are a total of 390 participants, 248 women (Mean.age $=25.07, S d=5.48$ ) and 142 men (Mean .age $=25.55, S d=5.23$ ), aged between 18-44. Insight Scale, Cognitive Flexibility Scale and Psychological Hardiness Scale were used to collect data. Pearson Correlation Analysis and Multiple Linear Regression analysis were used to analyze the data. It was found that there is a positive and statistically significant relationship between Insight Scale scores and the Cognitive Flexibility Scale scores $(r=.499, p<$ .01). It was determined that there is a positive and statistically significant relationship between Psychological Hardiness Scale scores with Insight Scale scores $(r=.450, p<.01)$ and Cognitive Flexibility Scale scores $(r=$ $.599, p<.01)$. Also, it was observed that the Insight Scale scores $(\beta=.201, t=4.391, p=.000)$ and Cognitive Flexibility Scale scores $(\beta=.498, t=10.872, p=.000)$ significantly predicted the Psychological Hardiness Scale scores. According to the results of the research, insight and cognitive flexibility explain $38 \%$ of the total variance of psychological hardiness. The results of the research showed that the cognitive structures in particular and the psychological structures in general have an interactive and dynamic structure, and therefore the obvious importance of understanding each concept in psychological support services offered to people.
\end{abstract}

Key Words: Insight, Cognitive Flexibility, Psychological Hardiness, Awareness, Cognitive Processes

\footnotetext{
${ }^{1}$ Res. Assist. Beykent University, Department of Psychology, İstanbul-Turkey,Orcid İd: https://orcid.org/ 0000-0002-78086583

${ }^{1}$ Res. Assist. Beykent University, Department of Psychology, İstanbul-Turkey, Orcid İd: https://orcid.org/ 0000-0001-65263512

${ }^{2}$ Asst. Prof. Dr. Marmara University, Department of Educational Sciences, İstanbul-Turkey, Orcid İd: https://orcid.org/ 0000-0002-8318-9026
}

Address of Correspondence/Yazışma Adresi: Beykent University, Department of Psychology, İstanbul-Turkey, E-mail: eneskaya@beykent.edu.tr

Date of Received/Geliş Tarihi: 03.01.2021, Date of Revision/Düzeltme Tarihi: 09.02.2021, Date of Acceptance/Kabul Tarihi: 16.02.2021, Date of Online Publication/Çevirimiçi Yayın Tarihi: 01.03 .2021

Citing/Referans Gösterimi: Kaya, E.M., Eken, O.F., Ümmet, D. (2021). The Predictor Effect of Insight and Cognitive Flexibility on Psychological Hardiness, Cyprus Turkish Journal of Psychiatry \& Psychology, 3(1): 22-29

(C) 2020 The Author(s). Published by Cyprus Mental Health Institute / Cyprus Turkish Journal of Psychiatry and Psychology (www.ktppdergisi.com). This article is an open access article distributed under the terms and conditions of the Creative Commons Attribution 4.0 license which permits use, sharing, adaptation, distribution and reproduction in any medium or format, provided the original work is properly cited and is not used for commercial purposes. http://creativecommons.org/licenses/by/4.0/ 


\section{Öz:}

$\mathrm{Bu}$ çalışmada, içgörü ve bilişsel esnekliğin psikolojik dayanıklılık üzerindeki etkisinin incelenmesi amaçlanmıştır. Araştırmanın çalışma grubunda, yaşları 18-44 $($ Ort. $=24.00 \mathrm{Ss}=5.79)$ aralı̆̆ıında olan 248 kadın $($ Ort.yas $=25.07, S=5.48)$ ve 142 erkek (Ort.yas $=25.55, S s=5.23)$ olmak üzere toplam 390 kat1lımc1 bulunmaktadır. Verilerin toplanmasında İçgörü Ölçeği, Bilişsel Esneklik Ölçeği ve Psikolojik Dayanıklılık Ölçeği kullanılmıştır. Veriler analiz edilirken Pearson Korelasyon Analizi ve Çoklu Doğrusal Regresyon analizi kullanılmıştır. İçgörü Ölçeği puanları ile Bilişsel Esneklik Ölçeği puanları arasında pozitif yönlü ve istatistiksel olarak anlamlı bir ilişki olduğu belirlenmiştir $(r=.499, p<.01)$. Psikolojik Dayanıklılık Ölçeği puanları ile İçgörü Ölçeği puanları $(r=.450, p<.01)$ ve Bilişsel Esneklik Ölçeği puanları $(r=.599, p<.01)$ arasında da pozitif yönlü ve istatistiksel olarak anlamlı bir ilişki olduğu belirlenmiştir. İçgörü Ölçeği puanlarının $(\beta=.201, t=4.391, p=$ .000) ve Bilişsel Esneklik Ölçeği puanlarının $(\beta=.498, t=10.872, p=.000)$ Psikolojik Dayanıklılık Ölçeği puanlarını istatistiksel olarak anlamlı biçimde yordadığı görülmüştür. Araştırma sonuçlarına göre içgörü ve bilişsel esneklik, psikolojik dayanıklılı̆ga ait toplam varyansın \%38'ini açıklamaktadır. Araştırma sonuçları, özelde bilişsel, genelde ise psikolojik yapıların etkileşimli ve dinamik bir yapıda olduğunu, dolayısıyla insanlara sunulan psikolojik destek hizmetlerinde her bir kavramı anlayabilmenin açık önemini göstermiştir.

Anahtar Kelimeler: İçgörü, Bilişssel Esneklik, Psikolojik Dayanıklılık, Farkındalık, Bilişsel Süreçler

\section{Giriş}

İnsan deneyimlerini anlamlı ve değerli kılabilmeyi amaçlayan duygu, düşünce ve davranışların odağında bulunan içgörü kavramı, insan psikolojisine dair temel yapılardan biri olarak değerlendirilmektedir (Beitel, Ferrer ve Cecero, 2005). İçgörü, kişinin kendi iç dünyasını ve sorunlarını anlama kapasitesi olarak tanımlanabilse de kullanıldığı bağlama göre kavramın kapsamına dair farklı görüşler bulunmaktadır (Harrington, Loffredo ve Perz, 2014). İçgörü, sözlük anlamında ayırt etme, anlayış ve bilgelik kavramlarıyla birlikte ele alınmakta ve bir şeye dair görme yetisi, ruhsal görüş ya da anlayış olarak tanımlanmaktadır. Teknik anlamda, psikolojik olarak çözümü hızla kavrama, biçimsel öğrenme, bireyin kendisini diğerlerinin gördüğü gibi görebilmesi ve kendilik bilgisi şeklinde açıklanan içgörü kavramı, psikiyatride ise hastanın ruhsal bir hastalığ1 olduğunun farkında olması ve bu hastalığın semptomlarını fark edebilme düzeyi anlamında kullanılmaktadır (Aslan ve Altınöz, 2010). Psikolojik büyümenin ve sağlıklı gelişimin bir göstergesi olarak kabul edilen içgörü kavramına 20. yüzyılın başlarında dikkat çekilmeye başlanmış ve psikolojik müdahalelerde başlıca çalışma gündemlerinden biri haline gelerek merkezi bir noktada konumlandırılmıştır (Lehmann ve Hilsenroth, 2011). Psikolojik yardım süreçlerinde bireylerin içgörü kazanması, kendi güç ve yeterliliklerini fark edip işlevsellik düzeylerini arttırabilmek açısından önemli görülmüştür (Akdoğan ve Türküm, 2014). Ne var ki, içgörüye dair yapılan çalışmaların sayısına tezat oluşturacak şekilde çok sayida ruhsal problemde içgörünün yeterince ele alınmadığı da belirtilmektedir (Fıstıkçı, Keyvan ve Cesur, 2016). Bu bağlamda değerlendirildiğinde içgörü, psikolojik dinamiklerin merkezi yapılarından biri olarak incelenmeye değer görülmektedir.

Bireylerin içinde bulundukları duruma dair farklı bakış açıları geliştirebilme ve alternatifler üzerine düşünebilme gibi esnekliğe temas eden yönüyle içgörü kavramı, bilişsel psikoloji açısından da ilgi görmüştür (Mutsatsa, Joyce, Hutton ve Barnes, 2006). Bilişsel psikoloji alanında esneklik kavramı, önemli bir bileşen olarak ele alınmakta, bunun yanı sira bireylerin esneklik gösterebilmeleri için önce bilişsel esnekliğe sahip olmaları gerektiği belirtilmektedir. Bilişsel esneklik; başka seçeneklerin ve alternatiflerin olduğuna dair farkındalık, yeni durumlara uyum sağlamaya ve esneklik göstermeye gönüllü olma ya da kişinin esnekliğine dair inancı olarak tanımlanabilir (Martin ve Rubin, 1995). Bilişsel esneklik, sorun yaşanan durumlarda farklı çözümler üzerine düşünme ve çok yönlü durumlarda işlevsel değişimler gerçekleştirebilme kapasitesini de içeren bilişsel bir beceri olarak da değerlendirilmektedir. Buradan yola çıkarak bilişsel esneklik, değişen çevresel koşullara göre bilişleri değiştirebilme yetisi olarak da ifade edilebilmektedir (Dennis ve Vander Wal, 2010). Bilişsel esnekliği gelişmiş bireyler, kendilerini zorlayan ve uyumsuz olan düşünceler yerine daha dengeli ve uyumlu düşünceler koyabilmekte, alternatifler üretebilmekte ve zorlayıcı durum ve olaylarla daha kolay baş edebilmektedir (Gülüm ve Dağ, 2012). Ancak bu detaylı tanımlar ve açıklamaların yanında bilişsel esnekliğin dinamikleri tam olarak anlaşılabilmiş değildir (Ionescu, 2012). İnsan doğasının önemli bir parçası olan bilişsel esneklik, farklı açılardan araştırılıp değerlendirilmesi gereken bir kavram olarak karşımıza çıkmaktadır.

Farkındalık, uyum sağlama ve seçenekleri değerlendirebilme noktalarında bir arada ele alınabilen içgörü ve bilişsel esneklik kavramları, psikolojik dayanıklılıkla iç içe geçmiş ve psikolojik dayanıklılığın kavramsal yapısında yer alan bileşenler durumundadır (Fahim-Devin, Farbod, Ghasabian, Bidel ve Ghahremanlou, 2015). Psikolojik dayanıklılık, stresli yaşam olaylarıyla etkili şekilde başa çıkmayı ifade eden ve ruh sağlı̆̆ının önemli belirleyicilerinden biri olarak kabul edilen bir kavramdır (Aflakseir, Nowroozi, Mollazadeh ve Goodarzi, 2016). Psikolojik dayanıklılığı yüksek olan bireylerin stres yaratan durumlara daha işlevsel tepkiler verdikleri ileri sürülmektedir (Kırca ve Saruhan, 2020). Psikolojik dayanıklılığın bireylere etkisi temel düzeyde üç aşamada değerlendirilebilir: 1) Stresli olayla karşıllaşmadan önce sağlanan koruyucu etki, 2) Stresli olayla etkili şekilde başa çıkabilme ve 3) Stresli olay sonrası eski işlevselliğe dönebilme (Akça-Koca ve Erden, 2018). Bu bağlamda, psikolojik dayanıklılığ yüksek bireylerin; zorlayıcı yaşam olaylarına karşı korunaklı oldukları, daha etkin mücadele gösterdikleri ve eski işlevselliklerine daha çabuk dönebildikleri söylenebilir. Psikolojik dayanıklılık; içsel, koruyucu, uyum sağlayıcı bazı faktörleri içinde barındıran, bireyin 
kendini toparlama gücünün de önemli bir göstergesidir (Terzi, 2008). Psikolojik dayanıklılık, bireylerin olumsuz yaşam olaylarıyla başa çıkmak için kendi içlerinde olumlu duygular geliştirebilmelerine, diğer bireyler ile olumlu ilişkiler kurabilmelerine imkân vermekte ve bu da sorunlarla başa çıkmayı kolaylaştıran destekleyici bir sosyal bağlam oluşturmaktadır (Demos, 1989; Werner ve Smith, 1992; Kumpfer, 1999).

İçgörü temelinde yapılan çalışmalara göre, düşük içgörü depresyon, (MacDougall vd., 2015), psikotik bozukluklar ve bu bozukluklardaki duygudurum belirtileri, duygudurum bozuklukları (Ghaemi, Boiman ve Goodwin, 2000) ile ilişkilendirilmektedir. Bilișsel esnekliğin, öz yeterlilik (Martin ve Rubin, 1995), yılmazlık ve başa çıkma becerileri (Soltani, 2013) ile ilişkili olduğu belirlenmiştir. Ayrıca, düşük düzeyde bilişşsel esnekliğin yüksek depresyon, dürtüsellik, ruminasyon ve anksiyete ile ilişkili olduğuna dair araştırmalar mevcuttur (Davis ve Nolen-Hoeksema, 2000; Marazziti, Consoli, Picchetti, Carlini ve Faravelli, 2010). Bu bağlamda, içgörü ve bilişsel esnekliğin arttırılmasının örseleyici yaşantılardan korunmada ve psikolojik sorunların tedavisinde önemli etkenler olduğu düşünülmektedir. Psikolojik dayanıklılık ise bireyin yaşamında karşılaştığ kaynaklarını yönetebilmesi için önemli bir faktördür (Ong, Bergeman, Bisconti ve Wallace, 2006). Bu sonuçlar değerlendirildiğinde, alanyazında bu konu üzerine yapılmış, üç değişkenin bir arada ele alındığ 1 çalışmanın bulunmadığı görülmüştür. Psikolojik rahatsızlıklardan korunmada ve bu problemlerle başa çıkmada oldukça önemli nitelikler olduğu düşünülen içgörü ve bilişsel esnekliğin, koruyucu ve destekleyici etkisinin psikolojik dayanıklılığı ne ölçüde etkilediğinin belirlenmesi önemli görülmektedir. $\mathrm{Bu}$ bağlamda araştırmada içgörü ve bilişsel esnekliğin psikolojik dayanıklılık üzerindeki yordayıcı etkisinin incelenmesi amaç edinilmiştir. Araştırma bulgularının ruh sağlı̆̆ alanında çalışan profesyonellere farklı bir bakış açısı verebileceği, ayrıca ilgili alanın bilgi birikimine katk1 sağlayacağı düşünülmektedir.

\section{Gereç ve Yöntem}

\section{Çalışma Grubu}

Araştırmanın çalışma grubunda, yaşları 18-44 (Ort.= $24.00 \mathrm{Ss}=5.79)$ aralığında olan 248 kadın (Ort.yas $=$ $25.07, S s=5.48)$ ve 142 erkek $($ Ort. .yas $=25.55, S s=5.23)$ olmak üzere toplam 390 katılımcı bulunmaktadır. Katılımcılar farklı mesleklerden ve sosyo-demografik yapılardaki bireylerden oluşmaktadır. Araştırmada kolay ulaşılabilir örnekleme yöntemi kullanılmıştır. Bu örnekleme yöntemi tamamen mevcut olan, ulaşması hızlı ve kolay olan öğelere dayanır ve araştırmacıya ekonomiklik sağlar, bir bakıma random bir seçim mevcuttur (Patton, 2005).

\section{Demografik Bilgi Formu}

Araştırmada katılımcıların demografik özellikleri hakkında (yaş ve cinsiyet) bilgi toplamak amacıyla araştırmacılar tarafından hazırlanan demografik bilgi formu kullanılmıştır.

\section{İçörrü Ölçeği}

Akdoğan ve Türküm (2018) tarafindan bireylerin içgörü düzeylerini ölçmek amacıyla geliştirilmiştir. Ölçekte 20 soru bulunmakta ve üç alt boyuttan oluşmaktadır. Ölçek, 1-5 aralığında puanlanan 5'li likert türündedir. Ölçekten en az 20 en fazla 100 puan alınabilmektedir. Ölçeğin boyutları, Bütüncül Bakma (3, 6, 11, 12, 14, 15, 18 sayılı maddeler), Kendini Kabul (2, 4, 5, 9, 13, 17, 19) ve Kendini Anlama $(1,7,8,10,16,20)$ şeklinde düzenlenmiştir. Ölçeğin alt boyutlarından alınan yüksek puan içgörünün ilişkili olduğu o boyuttaki düzeyin yüksekliğini göstermektedir. Ölçeğin tamamından elde edilen puanlar içgörü düzeyinin yüksekliğini göstermektedir. Geçerlilik çalışmasında toplam varyansın \%45,24'ünü açıklayan üç boyutlu bir yapı elde edilmiştir. Ölçek maddelerinin ise faktör yüklerinin .33- .63 aralığında olduğu görülmüştür. Ölçeğin Cronbach Alfa iç tutarlılık katsayısı .84 , alt boyutlarının ise sirasiyla .80 , .69 ve .78 olarak hesaplanmıştır.

\section{Bilişsel Esneklik Ölçeği}

Bilişsel Esneklik Ölçeği, Martin ve Rubin (1995) tarafından bireylerin bilişsel esnekliklerini belirlemek amacıyla geliştirilmiştir. 12 maddeli ve tek boyutlu bir yapıdadır. 1-6 aralığında puanlanmakla birlikte 6'l Likert tipi şeklinde düzenlenmiştir. Ölçekten en az 12, en fazla 72 puan alınabilmektedir. Ölçekten alınan puanların artması bilişsel esnekliğin arttığını göstermektedir. 2, 3, 6 ve 10. maddeler ters puanlanmaktadır. Ölçeğin orijinal çalışmasında Cronbach Alfa iç tutarlılık katsayısı .72, .73 ve .81 olarak bulunmuştur. BEÖ puanları ile iletişim becerileri ve iletişim becerilerine yönelik davranışlardaki yetkinlik inancı puanları arasında pozitif yönde anlamlı bir ilişkinin olması, bireylerin bilişsel esneklik düzeyi yükseldikçe olumlu arkadaşlık kurdukları yönündeki bulguların da BEÖ'nün ölçüt bağıntılı geçerliğine yönelik kanttlar olduğu düşünülmüştür (Martin ve Rubin, 1995; Martin vd.,1998). Çelikkaleli (2014) tarafindan yapılan Türkçe'ye uyarlama çalışmasında ise, ölçeğin yapı geçerliliği test edilmiş, Faktör yüklerinin .20 ile .74 aralığında değiştiği, ölçeğin 5,3'lük bir özdeğere sahip olduğu; bilişsel esneklik puanlarındaki varyansı \%43 oranında açıklayan tek faktörlü yapıda olduğu görülmüştür. 2. madde ölçeğin iç tutarlıllğında probleme neden olması sebebiyle ölçekten çıkarılmıştır. Cronbach Alfa iç tutarlılık katsayısı .74 ve test-tekrar test güvenirlik katsayısı ise .98 olarak hesaplanmıştır. İki yarı güvenirliği ise .77 olarak bulunmuştur.

\section{Psikolojik Dayanıklılık Ölçeği}

Psikolojik Dayanıklılık Ölçeği, Işık (2016) tarafından bireylerin psikolojik dayanıklılıklarını ölçmek amacıyla geliştirilmiştir. Ölçek 21 maddeden oluşmakta olup üç alt boyutu bulunmaktadır. 5'li likert türünde geliştirilen ölçek 0-4 aralığında puanlanmaktadır. Ölçeğin alt boyutları, meydan okuma, kendini adama ve kontrol olarak adlandırılmıştır. Ölçekten en az 0 , en fazla ise 84 puan alınabilmektedir. Ölçekten alınan puanların artması psikolojik dayanıklılığın arttığı anlamına gelmektedir. Çalışma sonuçlarına göre, özdeğerleri 1.00'in üzerinde olan üç faktörün ölçeğe ilişkin açıkladığı varyansın $\% 49.61$ olduğu ortaya çıkmıştır. Meydan okuma alt boyutu faktör yükleri .46 ile .69 arasında değişen yedi maddeden oluşmakta, toplam varyansın \%3.21'ini açıklamaktadır. Kendini adama alt boyutu faktör yükleri .44 ile .62 arasında değişen ve toplam varyansın \% 7.41 'ni 
açıklayan yedi maddeden oluşmaktadır., Kontrol alt boyutu ise faktör yükü .37 ile .66 arasında değişen ve toplam varyansın \%7,99'unu açıklayan yedi maddeden oluşmaktadır. Ölçeğin tümü için hesaplanan Cronbach Alfa iç tutarlılık katsayısı .76 iken, alt boyutlar için Cronbach Alfa iç tutarlılık katsayıları .62 ile .74 arasındadır.

\section{İşlem}

Araştırmada İlk adımda, Beykent Üniversitesi Sosyal ve Beşeri Bilimler için Yayın Etiği Kurulu'ndan etik onay alınmıştır (03.11.2020). İkinci adımda, katılımcılardan gönüllü onamları alınarak araştırmada kullanılan ölçme araçları katılımcılar tarafından doldurulmuştur. Araştırmaya katılım gönüllülük esasına dayalı olarak sağlanmıştır. Katılımcıların ölçekleri yanıtlaması yaklaşık 20 dakika sürmüştür. Üçüncü adımda araştırma kapsamında toplanan veriler analiz edilmiştir. Son adımda ise araştırma bulguları ilgili alanyazın ışığında tartışılmış, konuya ilişkin öneriler getirilmiştir.

\section{Verilerin Analizi}

Betimsel veriler analiz edilirken ortalama ve standart sapma kullanılmıştır. Araştırmanın değişkenleri ile ilgili normallik varsayımı çarpıklık ve basıklık değerleri kullanılarak incelenmiştir. Basıklık ve çarpıklık değerlerinin $+1,5$ ve $-1,5$ arasında olması verilerin normal dağıldığının bir göstergesidir. (Tabachnick ve Fidell, 2013). Analiz sonucunda verilerin normal dağıldığı görülmüştür (Tablo 1). Araştırmada kullanılan ölçekler arasındaki ilişkinin incelenmesinde Pearson Korelasyon Analizi, yordayıc1 etkinin belirlenmesinde ise Çoklu Doğrusal Regresyon Analizi kullanılmıştır. Verilerin analizinde SPSS (Statistical Package Programme For Social Sciences) 24 paket programı kullanılmıştır.

\section{Bulgular}

$\mathrm{Bu}$ bölümde, araştırmadan elde edilen verilerin analiz edilmesiyle ulaşılan sonuçlara yer verilmiştir.

Tablo 1.

İçgörü Ölçeği, Bilişsel Esneklik Ölçeği ve Psikolojik Dayanıklılık Ölçeği Puanlarına İlişkin Betimsel İstatistikler

\begin{tabular}{lllllll}
\hline Ölçekler & Min & Max & Ort. & Ss & Çarpıklık & Basıklık \\
\hline İgörü Ölçeği & 51 & 94 & 75.21 & 7.39 & -.282 & .084 \\
Bilişsel Esneklik Ölçeği & 33 & 66 & 49.94 & 6.82 & -.158 & -.218 \\
Psikolojik Dayanıklılık Ölçeği & 26 & 74 & 54.43 & 8.58 & -.168 & -.044 \\
\hline
\end{tabular}

Araştırmada yer alan değişkenlere ilişkin en küçük ve en büyük değerler, ortalama, standart sapma, çarpıklık ve basıklık değerleri Tablo 1'de verilmiştir. Regresyon analizi öncesinde araştırmada kullanılan değişkenler

\section{Tablo 2.}

Íçgörü Ölçeği, Bilişsel Esneklik Ölçeği ve Psikolojik Dayanıklılık Ölçeği Puanları Arasındaki İlişkilere Yönelik Pearson Korelasyon Analizi

\begin{tabular}{llll}
\hline Değişkenler & ÏÖ & BEÖ & PDÖ \\
\hline İçgörü Ölçeği (İÖ) & 1 & & \\
Bilişsel Esneklik Ölçeği (BEÖ) & $.499^{* *}$ & 1 & $.599^{* *}$ \\
Psikolojik Dayanıklılık Ölçeği (PDÖ) & $.450^{* *}$ & 1 \\
\hline
\end{tabular}

$*<0,05 ; * *<0,01$

İçörü Ölçeği puanları ile Bilişsel Esneklik Ölçeği arasında pozitif yönlü ve istatistiksel olarak anlamlı bir ilişki olduğu belirlenmiştir $(r=.499, p<.01)$. Psikolojik Dayanıklılık Ölçeği puanları ile İçörü Ölçeği puanları $(r=.450, p<.01)$ ve Bilişsel Esneklik Ölçeği puanları $(r=$ $.599, p<.01)$ arasında da pozitif yönlü ve istatistiksel olarak anlamlı bir ilişki olduğu belirlenmiştir. $\mathrm{Bu}$ bulgulara göre katılımcıların içgörü ve bilişsel esneklik düzeyleri arttıkça psikolojik dayanıklılıkları da artmaktadır. arasındaki ilişkiler incelenmiştir. İçgörü, bilişsel esneklik ve psikolojik dayanıklılık arasındaki ilişkileri belirlemeye yönelik yapılan Pearson Korelasyon analizinin sonuçları Tablo 2'de sunulmuştur.

\section{Tablo 3.}

Korelasyon analizinin sonrasında, İçgörü Ölçeği ve Bilişsel Esneklik Ölçeği puanlarının Psikolojik Dayanıklılık ölçeği puanları üzerindeki yordayıcı etkilerinin incelenmesi amaciyla çoklu doğrusal regresyon analizi uygulanmıştır. Regresyon analizlerinden geçerli sonuçlar elde edilebilmesi için kurgulanan regresyon modellerinin sağlaması gereken bazı varsayımlar bulunmaktadır (Güriş ve Astar, 2014; Tabachnick ve Fidell, 2007). Bu kapsamda regresyon varsayımları incelenmiş ve bulgular Tablo 3'te sunulmuştur.

Kurgulanan Regresyon Modelleri için Regresyon Varsayımlarının Sinanması

\begin{tabular}{|c|c|c|c|c|c|c|c|}
\hline \multicolumn{4}{|c|}{ Çoklu Doğrusal Bağıntı Varsayımı } & \multirow{3}{*}{$\begin{array}{c}\begin{array}{c}\text { Otokorelasyon } \\
\text { Varsayımı }\end{array} \\
\text { Durbin Watson }\end{array}$} & \multirow{3}{*}{$\begin{array}{l}\text { Artık Değerlerin } \\
\text { Normalliği } \\
\text { Çarpıklık: } .107\end{array}$} & \multirow{2}{*}{\multicolumn{2}{|c|}{$\begin{array}{l}\text { Artık DeğerlerinSabit } \\
\text { Ortalaması }\end{array}$}} \\
\hline & & & & & & & \\
\hline$\overline{\text { VIF }}$ & Tolerance & $\mathbf{E V}$ & CI & & & .000 & $\chi 2(5)=4,29$ \\
\hline 1.331 & .751 & .010 & 17.600 & 1.942 & Basıklık: .267 & & \\
\hline 1.331 & .751 & .005 & 25.631 & & & & \\
\hline
\end{tabular}

Çoklu doğrusal bağlantı varsayımı, tolerans değerleri, varyans enflasyon faktörü (VIF), özdeğer (eigenvalue) ve koşul indeks (CI) değerleri ile değerlendirilmiştir. Tolerans değerlerinin .20-1.00 ve VIF değerlerinin 1.00-
10.00 aralığında bulunduğu belirlenmiştir. Ayrıca, özdeğerlerin 15 'ten, CI değerlerinin ise 30 'dan az olduğu görülerek çoklu doğrusal bağlantı sorununun bulunmadığ $\breve{g}_{1}$ sonucuna ulaşılmıştır. Durbin Watson 
değerinin 2'ye yakın olduğu belirlenmiş ve hata terimlerinin bağımsızlığı varsayımının da sağlandığı saptanmıştır. Bunun yanı sıra, artık değerlerin çarpıklık ve basıklık değerlerinin $+1,5$ ve $-1,5$ aralığında bulunarak normal dağılım varsayımını karşıladığı ve ortalamalarının da ' 0 ' olduğu belirlenmiştir. Dolayısıyla artık değerlerin normalliği ve artık değerlerin ortalaması varsayımlarının da karşılandığı gözlenmiştir. Son olarak sabit varyans varsayımının incelenmesi amaciyla White testi kullanılarak yardımcı bir regresyon modeli kurulmuştur. Yapılan analiz sonucunda sabit varyans varsayımının da karşılandığı belirlenmiştir. Yordanan ve yordayıcı Tablo 4.

İçgörü Ölçeği Puanları ve Bilişsel Esneklik Ölçeği Puanlarının Psikolojik Dayanıklılık Ölçeği Puanları Üzerindeki Yordayıcı Etkisinin İncelenmesi Amacıla Kurulan Çoklu Doğrusal Regresyon Analizi Sonuçları

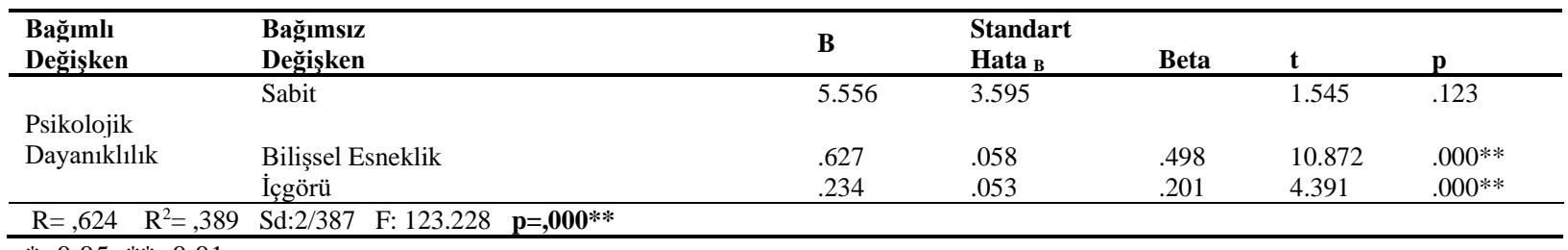

$*<0,05 ; * *<0,01$

Psikolojik Dayanıklılık Ölçeği puanlarının yordayıcılarını belirlemek amaciyla çoklu doğrusal regresyon analizi uygulanmışıtır. Regresyon modeli kurgulanırken 'Stepwise' yöntemi tercih edilmiştir. Kurgulanan regresyon modelinde Psikolojik Dayanıklılık Ölçeği puanlarının yordayıcıları olarak İçgörü Ölçeği ve Bilişsel Esneklik Ölçeği puanları alınmış ve kurulan modelin istatistiksel olarak anlamlı olduğu görülmüştür $\left(F_{(2-387)}=\right.$ $30.390, p=.00)$. Modelin açıklayıcılık gücü $\% 38,9$ olarak hesaplanmıştır. Psikolojik Dayanıklılık Ölçeği puanlarının yordayıcısı olarak İçörü Ölçeği puanlarının $(\beta=.201, t=4.391, p=.039)$ ve Bilişsel Esneklik Ölçeği puanlarının $(\beta=.498, t=10.872, p=.00)$ anlaml 1 parametreler olduğu bulunmuştur.

\section{Tartışma}

Araştırmadan elde edilen verilerin analiz sonuçlarına göre araştırmanın üç değişkeni arasında da anlamlı ilişkiler olduğu görülmüş, içgörü ve bilişsel esnekliğin psikolojik dayanıklılığı anlamlı şekilde ve pozitif yönde yordadığı görülmüştür. Alanyazında, araştırmanın bağımsız değişkenleri olan içgörü ve bilişsel esneklik arasındaki anlamlı ilişkiyi destekleyen ve paralel sonuçlara ulaşan çalışmalar bulunmaktadır (Chung, Su ve Su, 2012; Wang Bing, Jing, Chang ve Yuan, 2013). İçörü kavramı, temel yapısında alternatifleri fark etme ve çözüm için farklı yollar düşünebilme gibi esneklik temelinde bilişsel becerileri ve fonksiyonel tepkileri de içermektedir (Mutsatsa, Joyce, Hutton ve Barnes, 2006). İçgörüsü yüksek insanlar, farklılıkları tanımada ve bunlara açık olmakta daha geniş bir potansiyele sahipken, içgörü yoksunluğu görülen kişilerde ise bilişsel esneklik ve bilgi işleme hızında bir sınırlılıkla karşılaşılmaktadır (Yaluğ, Tufan ve Kutlu, 2006). Psikolojik gelișim çatı kavram olarak ele alındığında, içgörü ve esneklik kavramları psikolojik gelişimin iki önemli bileşeni olarak belirmektedir. Psikoterapi yaklaşımlarında danışanın içgörü kazanması, genellikle başlangıç hedefi olarak belirlenmekte ve psikoterapi sürecinde merkeze alınmaktadır (Lehmann ve Hilsenroth, 2011; Timulak ve McElvaney, 2013). Psikolojik ve bilişsel esneklik de özellikle güncel psikoterapi ekolleri açısından psikoterapi değişkenler arasındaki ilişkileri belirlemek için Korelasyon katsayıları hesaplanmış ve .90 üzerinde bir korelasyon katsayısının bulunmadığı belirlenmiştir (Tablo 2). $\mathrm{Bu}$ sonuçlar değerlendirildiğinde tüm regresyon varsayımlarının karşılandığı belirlenerek verilerin regresyon analizine uygun olduğu görülmüss ve regresyon analizleri gerçekleştirilmiştir. Tablo 4'te İçgörü Ölçeği ve Bilişsel Esneklik ölçeği puanlarının Psikolojik Dayanıklılık Ölçeği puanları üzerindeki yordayıcı etkilerinin incelenmesine ilişkin çoklu doğrusal regresyon analizi sonuçları verilmiştir. sürecinin sonunda danışanın sosyal yaşamdaki işlevselliğini arttırmak üzere kazanması ve hayatındaki ilişkilerde aktif tutması beklenen çıktılardan biridir (Overholser, 2004; McHugh, 2011). Bu bağlamda psikoterapi sürecinde içgörü ve esneklik kavramları sıklıkla hem sonuç hem süreç amaçları arasında yer almaktadır. Bu durum da içgörü ve esneklik arasındaki pozitif ilişkinin doğasını ve boyutlarını açıklamakta açık işaretler sunmaktadır. Bununla birlikte araştırma sonuçlarından farklı olarak içgörü ile bilişsel esneklik ve ilişkili bilişsel süreçler arasında anlamlı ilişkinin bulunmadığını bildiren çalışmalar da bulunmaktadır (Xiang ve ark., 2012). Farklı sonuçlar bildiren söz konusu çalışmalar, hali hazırda psikiyatrik bozukluk tanısı almış kişilerle yürütülmüş̧ür. Dolayısıyla bozukluğun değişken doğasından kaynaklı etmenlerin, farklılığın muhtemel sebebi olabileceği sonucuna varılmıştır. Araştırmalarda kullanılan ölçme ve değerlendirme araçlarındaki farklılı̆̆ın da bu sonuca etki etmiş olabileceği düşünülmektedir.

Araştırmanın temel bulgusu olan içgörü ve bilişsel esnekliğin psikolojik dayanıklılık üzerindeki pozitif yordayıcı etkisini destekleyen benzer çalışmalara alanyazında rastlanmaktadır (Cowden ve Meyer-Weitz, 2016; Yaşar-Ekici ve Balcı, 2019). Yaşam içerisindeki stresli durumlarla baş etmede önemli bir faktör olarak gösterilen psikolojik dayanıklılığın, yapısal açıdan çözüm yollarına dair bir içgörü barındırdığ 1 (Darvishzadeh ve Bozorgi, 2016) ve olumsuz ya da olumlu duygulara, işlevsel ya da çarpıtılmış düşüncelere, sorunlara yönelik ya da çözüm odaklı tutumlara karşı bir içgörü geliştirmenin, psikolojik dayanıklılı̆̆ın gelişmesi için başlangıç noktası olabileceği ifade edilmektedir (Jackson, Firtko ve Edenborough, 2007). Bunun yanı sıra içgörü ve psikolojik dayanıklılık arasındaki pozitif ilişkinin her durumda bu kadar net ve tek yönlü olmayabileceği, stresli yaşam olaylarıyla başa çıkmada işlevsel tutumlar geliştirerek artan psikolojik dayanıklılığın bireylerdeki içgörüyü destekleyeceği de söylenebilmektedir (ClaussEhlers, 2008). Konuya ilişkin çalışma ve yorumların ortak noktası, içgörü ve psikolojik dayanıklılığın çoğu zaman iç içe ve birbirini etkiler durumda bulunduğudur. 
$\mathrm{Bu}$ durumun da içgörünün psikolojik dayanıklılık üzerindeki pozitif yordayıcıllı̆ına ve bu yordayıcılığın beklenilebilir olduğuna işaret ettiği düşünülmektedir. Houpy, Lee, Woodruff ve Pincavage (2017), konuya farklı bir açıdan yaklaşarak, bireylerin kendi psikolojik dayanıklılık seviyelerine dair içgörülerini gündeme getirmiş ve bu durum da bireylerin psikolojik dayanıklılıklarını ideal seviyeye getirebilmeleri için temel bir adım olarak ifade edilmiştir. Edward (2005), yaptığ nitel çalışmasında içgörü ve psikolojik dayanıklılık arasındaki pozitif ilişkiyi ruh sağlığı uzmanları açısından değerlendirmiştir. Araştırmanın bulgularına göre verilen psikolojik destek hizmetinin ve danışanlarla kurulan ilişkinin değerine dair geliştirilen içgörü, ruh sağlığ1 uzmanlarında psikolojik dayanıklılığ 1 desteklemekte ve verilen hizmetin psikolojik ağırlığıyla daha etkili şekilde baş edebilme imkânı vermektedir. Bununla birlikte Hanfstingl (2013), yaptığı çalışmada beklenenin aksine içgörü ve psikolojik dayanıklılık arasında negatif bir ilişki bulmuş ve bu durumun örneklemdeki katılımcıların 40 yaş ve üzeri olmasından kaynaklanabileceğini belirtmiştir. İlerleyen yaşla birlikte insanlar belirsizliğe karşı daha açık hale gelebilmekte ve içinde bulunulan duruma dair farkındalığın artması, psikolojik dayanıklılık özelinde baş etme mekanizmalarını olumsuz etkileyebilmektedir.

Bilişsel esnekliğin psikolojik dayanıklılık üzerindeki pozitif yordayıcılığı açılanırken ise psikolojik dayanıklılık açısından bilişsel esnekliğin anahtar bir rol üstlendiğine vurgu yapılmış (Parsons, Kruijt ve Fox, 2016) ve psikolojik dayanıklılığın duygusal ve bilişsel durumlara uyum sağlamadaki ve stres yönetimindeki dinamik yapısına dikkat çekilmiştir (Keith, Velezmoro ve O'brein, 2015). Psikolojik dayanıklilık, beklenen ve beklenmeyen zorlayıcı durumlara karşı bireylerin daha işlevsel olmasına ve başa çıkmaya dair motivasyonlarını yüksek tutmalarına katkı sağlamakta, bu işlevsellik hali de farklı durumlara karşı bir esneklik barındırmaktadır (Fletcher ve Sarkar, 2012). Bilişsel esnekliğin, bireylerin seçeneklerine dair bir öngörü içeren öz-yeterlilikle olumlu bir ilişkisinin olduğu (Doğan-Laçin ve Yalçın, 2019) ve bu ilişkiye dayalı uyum sağlama becerisini desteklediği belirtilmektedir (Yelpaze, 2020). Güleç (2020), ise bilişsel esneklik ve psikolojik dayanıklılık arasındaki ilişkide aracı bir model üzerine çalışmış ve bilişsel esneklikle psikolojik dayanıklılık ilişkisinde yaşam amaçlarının kısmi aracı rolü olduğunu ortaya koymuştur. Bilişsel esneklik, stresli durumlara karş1 düşünce ve tutumları olumlu yönde değiştirebilme imkânı sunarak sorunları daha başa çıkılabilir hale getirmekte (Overholser, 2004), sorunlarla baş edebilme gücünü kendinde gören bireyler ise daha sağlıklı ve işlevsel yaşam amaçları belirleyebilmektedir. Yaşamını böylesi amaçlarla destekleyen insanlar ise psikolojik açıdan daha dayanıklı hale gelebilmektedir. Yaşam içerisindeki stresli olaylara karşı daha işlevsel düşünceler geliştirebilmeyi içeren bilişsel esneklik, birey için yaşamın değerini artırarak bu ilişkiyi desteklemekte, psikolojik dayanıklılığı geliştirmektedir (Dennis ve Vander Wal, 2010). Hanks, Rapport, Waldron-Perrine ve Millis (2016), hem bu araştırma sonuçlarının hem de kendi araştırmalarında kurulan hipotezin aksine bilişsel esneklik ve psikolojik dayanıklılık arasında anlamlı bir ilişki bulamamıştır. Söz konusu araştırma, travmatik beyin hasarı geçiren kişilerde hasar sonrasındaki ilk beş yılda yapılmış ve değişkenler öz-bildirim ölçekleriyle değerlendirmeye alınmıştır. Katılımcıların özel sağlık şartlarının ölçek puanlarına yansıdığı ve ulaşılan sonucun bu durumun yansıması olduğu düşünülmektedir.

Araştırma sonuçları, özelde bilişsel, genelde ise psikolojik yapıların etkileşimli ve dinamik bir yapıda olduğunu, dolayısıyla insanlara sunulan psikolojik destek hizmetlerinde her bir kavramı anlayabilmenin açık önemini göstermiştir. Bununla birlikte konunun daha iyi anlaşılabilmesi ve detaylandırılabilmesi için araştırma konusu farklı örneklem ve ölçme araçlarıyla tekrarlanabilir. Araştırmada katılımcıların demografik özellikleri açısından herhangi bir değerlendirme yapılmamış; içgörü, bilişsel esneklik ve psikolojik dayanıklılık arasındaki ilişkiye dair açıklamalarla yetinilmiştir, konuya ilgi duyan araştırmacılar tarafından demografik değişkenler açısından da bir araştırma tasarlanabilir. Ayrıca konunun daha net anlaşılması için nitel araştırmalar tasarlanabilir. Çalışmanın değişkenleri olan içgörü, bilişsel esneklik ve psikolojik dayanıklılık düzeylerini artırmak adına hem okullar ve eğitim merkezlerinde hem de halka açık hizmet ortamlarında uygulama ve grup çalışmaları düzenlenebilir.

\section{Beyannameler}

Etik onay ve katılma izni

Çalışma, "Beykent Üniversitesi Sosyal ve Beşeri Bilimler için Yayın Etiği Kurulu" tarafından değerlendirilmiş ve onaylanmıştır (03.11.2020).

Araștırmaya katılım gönüllülük esasına dayalı olarak sağlanmıştır. Katılımcılardan gönüllü onamları alınarak araştırmada kullanılan ölçme araçları katılımcılar tarafından doldurulmuştur.

Yayın izni

Uygulanamaz.

Veri ve materyallerin mevcudiyeti

Mevcut çalışma sırasında kullanılan ve / veya analiz edilen veri kümeleri, makul talep üzerine ilgili yazardan temin edilebilir.

Çıkar çatışması

Yazarlar çıkar çatışması olmadığını beyan eder.

Finansman

Uygulanamaz.

Yazar katkıları

MEK makale konusunun belirlenmesine, verilerin toplanmasina ve ilgili literatür 1şığında tartışılıp yorumlanmasına katkı sağlamıştır.

FOE makale konusunun belirlenmesine, verilerin toplanmasina ve analiz edilmesine katkı sağlamıştır.

DÜ makalenin yazımında danışmanlık yapmış, gerekli yerlerde düzeltme ve eklemeler yaparak yazıya son halini vermiştir.

Tüm yazarlar makalenin son halini okumuş ve onaylamıştır.

Yazarların bilgileri

Uygulanamaz.

Teşekkür

Uygulanamaz. 


\section{Kaynaklar}

Aflakseir, A., Nowroozi, S., Mollazadeh, J., ve Goodarzi, M. A. (2016). The role of psychological hardiness and marital satisfaction in predicting posttraumatic growth in a sample of women with breast cancer in Isfahan. Iran J Cancer Prev. 9(4), 1-5. DOI: $10.17795 / \mathrm{ijcp}-4080$

Akça-Koca, D., ve Erden, S. (2018). Bilişsel davranışçı temelli grupla psikolojik danışma programının ergenlerin psikolojik dayanıklılı̆ına ve mizah düzeyine etkisi. Yaşam Becerileri Psikoloji Dergisi, 2(3), 61-72.

Akdoğan, R. ve Türküm, A. S. (2018) Insight Scale for Nonclinical University Students: Validity and Reliability Analysis. Measurement and Evaluation in Counseling and Development, $\quad 51(4), \quad 250-262, \quad$ DOI: 10.1080/07481756.2017.1413941

Akdoğan, R. ve Türküm, A. S. (2014). Psikolojik yardım sürecinde terapötik bir hedef olarak içgörü. Psikiyatride Güncel Yaklaşımlar, 6(4), 375. DOI: 10.5455/cap.20140210075748

Aslan, S., ve Altınöz, A. E. (2010). İçgörü kavramı ve şizofreni. Tekrarlayıcı Nitelikte Bir Travma Olarak Aile $\dot{I}_{c ̧ i}$ Şiddetin Psikoz ile İlişsisi, 23.

Astar, M., ve Güriş, S. (2015). SPSS ile İstatistik. Ankara: Der Yayınları.

Beitel, M., Ferrer, E., ve Cecero, J. J. (2005). Psychological mindedness and awareness of self and others. Journal of Clinical Psychology, 61(6), 739-750. DOI: 10.1002/jclp.20095

Chung, S. H., Su, Y. F. ve Su, S. W. (2012). The impact of cognitive flexibility on resistance to organizational change. Social Behavior and Personality: An International Journal, 40(5), 735-745. DOI: 10.2224/sbp.2012.40.5.735

Clauss-Ehlers, C. S. (2008). Sociocultural factors, resilience, and coping: Support for a culturally sensitive measure of resilience. Journal of Applied Developmental Psychology, 29(3), 197-212. DOI: 10.1016/j.appdev.2008.02.004

Cowden, R. G. ve Meyer-Weitz, A. (2016). Self-reflection and self-insight predict resilience and stress in competitive tennis. Social Behavior and Personality: An International Journal, 44(7), 1133-1149. DOI: 10.2224/sbp.2016.44.7.1133

Çelikkaleli, Ö. (2014). Bilişsel Esneklik Ölçeği’nin geçerlik ve güvenirliği. Eğitim ve Bilim, 39(176), 339-346. DOI: 10.15390/EB.2014.3466

Darvishzadeh, K. ve Bozorgi, Z. D. (2016). The relationship between resilience, psychological hardiness, spiritual intelligence, and development of the moral judgement of the female students. Asian Social Science, 12(3), 170-176. DOI: $10.5539 /$ ass.v12n3p170

Davis, R. N., ve Nolen-Hoeksema, S. (2000). Cognitive inflexibility among ruminators and nonruminators. Cognitive Therapy and Research, 24(6), 699-711.

Demos, V., Dugan, T. F., ve Coles, R. (1989). The child in our times: Studies in the development of resiliency. Resiliency in Infancy, 3-22.

Dennis, J. P., ve Vander Wal, J. S. (2010). The Cognitive Flexibility Inventory: Instrument development and estimates of reliability and validity. Cognitive Therapy and Research, 34(3), 241-253. DOI:10.1007/s10608-009-9276-4

Doğan-Laçin, B. G. ve Yalçı, İ. (2019). Üniversite ögrencilerinde öz-yeterlilik ve stresle başa çıkma stratejilerinin bilişsel esnekliği yordama düzeyleri. Hecettepe Üniversitesi Eğitim Fakültesi Dergisi, 34(2), 358-371. DOI: 10.16986/HUJE.2018037424

Edward, K. L. (2005). The phenomenon of resilience in crisis care mental health clinicians. International Journal of Mental Health Nursing, 14(2), 142-148.
Fahim-Devin, H., Farbod, D., Ghasabian, H., Bidel, T. ve Ghahremanlou, F. (2015). Comparative and correlative study of psychological hardiness and competitiveness among female student athletes in individual and team sports. Sport Science Review, 24(3), 201-214. DOI: 10.1515/ssr-2015-0016

Fıstıkçı, N., Keyvan, A. ve Cesur, E. (2016). Psikiyatrik hastalıklarda içgörü kavramı: Bir gözden geçirme. Yeni Symposium, 54 (2), 25-29.

Fletcher, D. ve Sarkar, M. (2012). A grounded theory of psychological resilience in olympic champions. Psychology of Sport and Exercise, 13(5), 669-678. DOI: 10.1016/j.psychsport.2012.04.007

Ghaemi, S. N., Boiman, E., ve Goodwin, F. K. (2000). Insight and outcome in bipolar, unipolar, and anxiety disorders. Comprehensive Psychiatry, 41(3), 167-171. DOI: 10.1016/s0010-440x(00)90043-9

Güleç, S. (2020). Lise öğrencilerinde bilişsel esneklik ile psikolojik sağlamlık arasındaki ilişkide yaşam amaçlarının aracı rolü. Gelişim ve Psikoloji Dergisi, 1(1), 27-35.

Gülüm, I. V. ve Dağ, İ. (2012). Tekrarlayıcı Düşünme Ölçeği ve Bilişsel Esneklik Envanterinin Türkçeye uyarlanması, geçerliliği ve güvenilirliği. Anadolu Psikiyatri Dergisi, 13(3), 216-223.

Hanfstingl, B. (2013). Ego and spiritual transcendence: Relevance to psychological resilience and the role of age. Evidence-Based Complementary and Alternative Medicine, 2013, 1-9. DOI: 10.1155/2013/949838

Hanks, R. A., Rapport, L. J., Waldron Perrine, B. ve Millis, S. R. (2016). Correlates of resilience in the first 5 years after traumatic brain injury. Rehabilitation Psychology, 61(3), 269-276. DOI: 10.1037/rep0000069

Harrington, R., Loffredo, D. A., ve Perz, C. A. (2014). Dispositional mindfulness as a positive predictor of psychological well-being and the role of the private selfconsciousness insight factor. Personality and Individual Differences, 71, 15-18. DOI: 10.1016/j.paid.2014.06.050

Houpy, J. C., Lee, W. W., Woodruff, J. N. ve Pincavage, A. T. (2017). Medical student resilience and stressful clinical events during clinical training. Medical Education Online, 22(1), 1-8. DOI: $10.1080 / 10872981.2017 .1320187$

Ionescu, T. (2012). Exploring the nature of cognitive flexibility. New Ideas in Psychology, 30(2), 190-200. DOI: 10.1016/j.newideapsych.2011.11.001

Işık, Ş. (2016). Psikolojik Dayanıklılık Ölçeği’nin geliştirilmesi: Geçerlik ve güvenirlik çalıșması. The Journal of Happiness \& Well-Being, 4(2), 165-182.

Jackson, D., Firtko, A. ve Edenborough, M. (2007). Personal resilience as a strategy for surviving and thriving in the face of workplace adversity: A literature review. Journal of Advanced Nursing, 60(1), 1-9. DOI: 10.1111/j.1365-2648.2007.04412.x

Keith, J., Velezmoro, R. ve O'Brien, C. (2015). Correlates of cognitive flexibility in veterans seeking treatment for posttraumatic stress disorder. The Journal of nervous and mental disease, 203(4), 287-293. DOI: 10.1097/NMD.0000000000000280

Kırca, B. ve Saruhan, V. (2020). Pozitif psikoloji ekseninde bașa çıkma. D. Ümmet (Ed.) Tüm kavram ve yaklaşımlarıyla pozitif psikoloji içinde (143-160. Ss.). Ankara: Pegem.

Kumpfer, K. L., Glantz, M. D., ve Johnson, J. L. (1999). Resilience and development: Positive life adaptations. New York: Kluwer Academic.

Lehmann, M. E., ve Hilsenroth, M. J. (2011). Evaluating psychological insight in a clinical sample using the ShedlerWesten Assessment Procedure. The Journal of Nervous and 


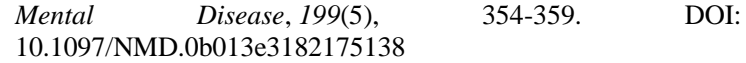

MacDougall, A. G., Vandermeer, M. R. J., ve Norman, R. M. G. (2015). Negative future self as a mediator in the relationship between insight and depression in psychotic disorders. Schizophrenia Research, 165(1), 66-69. DOI: 10.1016/j.schres.2015.03.035

Mantella, R. C., Butters, M. A., Dew, M. A., Mulsant, B. H., Begley, A. E., Tracey, B. ve Lenze, E. J. (2007). Cognitive impairment in late-life generalized anxiety disorder. The American Journal of Geriatric Psychiatry, 15(8), 673679. DOI:10.1097/jgp.0b013e31803111f2

Marazziti, D., Consoli, G., Picchetti, M., Carlini, M., ve Faravelli, L. (2010). Cognitive impairment in major depression. European Journal of Pharmacology, 626(1), 83-86. DOI: 10.1016/j.ejphar.2009.08.046

Martin, M. M., ve Rubin, R. B. (1995). A new measure of cognitive flexibility. Psychological Reports, 76(2), 623626. DOI: $10.2466 /$ pro.1995.76.2.623

Martin, M. M., Anderson, C. M. ve Thweatt, K. S. (1998). Aggressive communication traits and their relationship with the cognitive flexibility scale and the communication flexibility scale. Journal of Social Behavior and Personality, 13(3), 531540.

McHugh, L. (2011). A new approach in psychotherapy: ACT (acceptance and commitment therapy). The World Journal of Biological Psychiatry, 12(1), 76-79. DOI: 10.3109/15622975.2011.603225

Mutsatsa, S. H., Joyce, E. M., Hutton, S. B. ve Barnes, T. R. (2006). Relationship between insight, cognitive function, social function and symptomatology in schizophrenia. European Archives of Psychiatry and Clinical Neuroscience, 256(6), 356363. DOI: 10.1007/s00406-006-0645-7

Ong, A. D., Bergeman, C. S., Bisconti, T. L., ve Wallace, K. A. (2006). Psychological resilience, positive emotions, and successful adaptation to stress in later life. Journal of Personality and Social Psychology, 91(4), 730-749. DOI: 10.1037/0022-3514.91.4.730

Overholser, J. C. (2004). Contemporary psychotherapy: Moving beyond a therapeutic dialogue. Journal of Contemporary Psychotherapy, 34(4), 365-374.
Parsons, S., Kruijt, A. W. ve Fox, E. (2016). A cognitive model of psychological resilience. Journal of Experimental Psychopathology, 7(3), 296-310. DOI:10.5127/jep.053415

Patton, M. Q. (2005). Qualitative research. New York: John Wiley \& Sons, Ltd.

Shen, W., Luo, J., Liu, C. ve Yuan, Y. (2013). New advances in the neural correlates of insight: A decade in review of the insightful brain. Chinese Science Bulletin, 58(13), 1497-1511. DOI: $10.1007 / \mathrm{s} 11434-012-5565-5$

Soltani, E., Shareh, H., Bahrainian, S. A., ve Farmani, A. (2013). The mediating role of cognitive flexibility in correlation of coping styles and resilience with depression. Pajoohandeh Journal, 18(2), 88-96.

Tabachnick, B. G., ve Fidell, L. S. (2013). Using multivariate statistics, 6th Ed. Northridge. CA: California State University.

Tabachnick, B. G., Fidell, L. S., \& Ullman, J. B. (2007). Using multivariate statistics. Boston, MA: Pearson.

Terzi, Ş. (2008). Üniversite öğrencilerinin psikolojik dayanıklılıkları ve algıladıkları sosyal destek arasındaki ilişki. Türk Psikolojik Danışma ve Rehberlik Dergisi, 3(29), 111.

Timulak, L. ve McElvaney, R. (2013). Qualitative meta-analysis of insight events in psychotherapy. Counselling Psychology Quarterly, 26(2), 131-150. $10.1080 / 09515070.2013 .792997$

Werner, E. E., ve Smith, R. S. (1992). Overcoming the odds: High risk children from birth to adulthood. New York, Cornell University Press.

Xiang, Y. T., Wang, Y., Wang, C. Y., Chiu, H. F., Chen, Q., Chan, S. S., .....Ungvari, G. S. (2012). Association of insight with sociodemographic and clinical factors, quality of life, and cognition in Chinese patients with schizophrenia. Comprehensive Psychiatry, 53(2), 140-144. DOI: 10.1016/j.comppsych.2011.04.001

Yaluğ, İ., Tufan, A. E. ve Kutlu, H. (2006). Şizoafektif bozuklukla karısan bir erken demans olgusu. Anadolu Psikiyatri Dergisi, 7, 248-252.

Yaşar-Ekici, F., ve Balcı, S. (2019). Okul öncesi öğretmen adaylarının bilişsel esneklik düzeyleri ve duygusal tepkisellik düzeylerinin incelenmesi. Yüksekögretim ve Bilim Dergisi, 9(1), 65-77. DOI: $10.5961 /$ jhes.2019.310 